317 | juillet-septembre 1999

Numéro spécial : France-Allemagne. Interactions, références

\title{
Michel PERONNET (1931-1998)
}

\section{Geneviève Gavignaud-Fontaine}

\section{(2) OpenEdition \\ 1 Journals}

Édition électronique

URL : https://journals.openedition.org/ahrf/277

DOI : $10.4000 /$ ahrf.277

ISSN : 1952-403X

Éditeur :

Armand Colin, Société des études robespierristes

Édition imprimée

Date de publication : 1 septembre 1999

Pagination : $567-568$

ISSN : 0003-4436

\section{Référence électronique}

Geneviève Gavignaud-Fontaine, « Michel PERONNET (1931-1998) », Annales historiques de la Révolution française [En ligne], 317 | juillet-septembre 1999, mis en ligne le 16 avril 2004, consulté le 01 mai 2022. URL: http://journals.openedition.org/ahrf/277 ; DOI : https://doi.org/10.4000/ahrf.277

Ce document a été généré automatiquement le 1 mai 2022.

Tous droits réservés 


\section{Michel PERONNET (1931-1998)}

\section{Geneviève Gavignaud-Fontaine}

